\title{
Methodological Aspects of Estimation of Value of Specialized Property of Enterprises
}

\author{
Ruslan Volchek \\ Department of Accounting and Audit \\ Odessa National Economic University \\ Odessa, Ukraine \\ ruslan1981196@gmail.com
}

\begin{abstract}
The author's vision of the process of valuation of specialized property of enterprises, namely, industrial technological lines, is presented. The questions of expediency of use of the accounting-analytical instrument, which is capable to take into account the income component during determination of the value of specialized property are examined. It is presented the method of determination of the fair value of specialized property on the base of calculation and estimation of the special value of the property, as the amount of market value and its allowance. An instrument for determining the discount rate has been developed, which takes into account the peculiarities of the macroeconomic situation of the country, and the risks inherent to the use of specialized property of enterprises. The proposed methodology and developed methodological instrument for valuation of fair value of specialized property, will allow correctly to make management decisions about the production potential of the enterprise, which will further ensure its competitiveness.
\end{abstract}

Keywords-specialized property, special value, replacement or reproduction residual value, cost approach, revenue approach

\section{INTRODUCTION}

Business performance management requires the selection of non-standard measures for the use of enterprise assets in order to maintain their competitive advantages in the selected market segment. Management decisions are formed under the influence of the goals and interests of economic entities and, in accordance with the chosen business model, are embodied in the types of values that assess the «strategically important assets», that are able to ensure the management of companies to achieve the predicted market capitalization. These processes, in accordance with the unstable external environment of the enterprises of the real sector of the economy of Ukraine, encourage to carry out an asset restructuring procedures. Therefore, the development of accounting and analytical instrumentarium for valuation of property, the effective use of which in accordance with the specific features of the activity of any enterprise, is becoming especially relevant.

\section{OVER VIEW OF THE RELEVANT LITERATURE}

Historically, there are three main approaches to the valuation of an enterprise: expenditures (property); profitable; comparative (market). Cost Approach is often used for properties under construction or when there is limited market data available. However, a comparative approach is often used, which is based on the fact that the value of the enterprise - is the real sale price of a similar enterprise, that is, the enterprise value is calculated based on its results comparison with other business analogues [1]. By estimating the value of the company for potential investors, it is better to use a profitable approach that relies on analysis of the company's future earnings and profits and displays the ability to generate it stable cash flows. In general, the income approach is based on the analysis of cash flows and / or the determination of the economic profit of the company [2]. The profits method is more flexible and sophisticated than the cost approach in taking into account systematic and unsystematic risk. The profits method is more accurate than the cost approach in delivering a true reflection of the value of specialised property for any purpose but specifically for mortgage lending purposes and reduces the credit exposure risk of financial institutions. It also decreases pricing inefficiencies to be exploited by buyers and sellers [3]. The benefit of gaining immediate access to revenues by acquiring an existing operating asset (or by avoiding the delay in earning revenues) would typically manifest itself in the goodwill component of a business enterprise [4].

The comparative analysis of the bibliographic material, which deals with the peculiarities of determining the value of specialized property of enterprises, showed, that the attention of scientists and practitioners is focused on the study of the discussion aspects of valuation and accounting of assets depreciation process, as well as determining the fair value of assets and liabilities of companies undergoing restructuring procedure. In particular, I.V. Zhigley, and I.A. YukhimenkoNazaruk developed the procedure for determining and accounting for the asset impairment process under IFRS 36 «Impairment of Assets» (hereinafter referred to as IFRS 36), and disclosed the peculiarities of the sharing of the concept «cost in use» and «fair value» in the accounting system [5]. M.V. Koryakin formed a classification distribution of factors for generating and destroying enterprise values and developed a concept for constructing a methodology for accounting for enterprise value indicators based on the application of an integrated approach as for cost valuation [6]. V.N. Trishin emphasizes the problems of valuation of fixed assets by cost approach when estimating business value and argues, that the main discussion aspect when using cost approach is the valuation of specialized and quasi-specialized fixed assets, which have no market value (meaning, value is too problematic to determine), and the cost of which at the industrial enterprises is not less than $80 \%$ of the value of all fixed assets [7]. Therefore, V.N. Trishyn proposes a methodological approach to the determination of the value of specialized property, plant and equipment on the basis of the valuation base as the replacement cost [7]. 


\section{THE GAP, WHICH I ADDRESS TO IN MY STUDY}

International experience defines the peculiarities of determining the value of specialized property, which, in accordance with accounting terminology, is a component of the cash-generating unit; depending on the intentions to use the property in question, sets the different types of valuation at which it is valued. In accordance with IFRS 36 , if an asset will be used by an entity in accordance with current plans to execute a production program, it is accounted in terms of an amount, that does not exceed its cost of reimbursement. If an enterprise is undergoing restructuring, assets and liabilities are measured at fair value.

Despite the sufficiently clear position on accounting for specialized property, that exists today due to the use of international and national financial reporting standards by management personnel valuation of assets at fair value, that creates a mismatch between the goals and interests of restructuring entities. Since, usually, understand the market value, and the estimation of the market value of the property which cannot be bought on the market, and which is made by the individual order, leads to violation of the interests of the owners of this property, so a number of transactions are completed only at the stage of negotiations for activation of investment processes. In this regard, it is quite logical to formulate recommendations of a methodological and methodological nature for determining the value of specialized property of enterprises in accordance with the valuation base, which takes into account the interests of the owners of the said property.

\section{THE PURPOSE OF THE STUDY}

The purpose of the study is to develop accounting and analytical instrumentarium for valuation of specialized property of enterprises. The proposed instrumentarium will help to align the goals and interests of the restructured entities, and will be able to coordinate goals and interests of the subjects of restructuring, and will promote to use the correct tax base for transactions with specialized property of enterprises.

\section{PRESENTING OF THE MAIN MATERIAL}

At the initial stage of research will provide a description of the terms, that will be used in the future and understanding of their essence will allow to understand the essence and difference of accounting and analytical tools of valuation of the specialized property of the enterprises, offered by the author.

"Specialized property - is the property, whose use is the most useful only in the integral property complex [8]."

"According to IFRS 36, a cash-generating - is the smallest group of assets, that provides cash flows, that are mostly independent from cash flows from other assets or groups of assets [5]." The established standard provides for the calculation of impairment loss from depreciation of fixed assets.

Cash-generating units (hereinafter referred to as «CGU») - is a term that is more general than specialized property. However, because an international standards do not define the term «specialized property», in our study, specialized property will be understood as specialized equipment, namely, the processing line.

"Impairment loss - is the amount of money, over which the asset's carrying value exceeds its recoverable value [9]."

From a methodological point of view, it is advisable to give a comparative description of the international and domestic experience of valuing specialized property, in order to identify the debatable aspects, which, according our opinion, taking into no account of which, leads to cases of alienation and overestimation of property in domestic economic practice by participants of transactions.

In accordance with IFRS 16 «Capital assets» (hereinafter referred to as IFRS 16), the initial cost of the equipment may be calculated as the cost of manufacturing or equal to its fair value [10]

Further evaluation of fixed assets is carried out by the following models:

- cost model at cost price;

- the model of fair value measurement, namely the cost of replacement based on depreciation or the future income from the use of the asset.

"According to IFRS 16, depreciation-based replacement cost - is the cost of a new similar asset, net of depreciation, that would be accumulated over the term of the revalued asset[6]." Also, IFRS 36 indicates, that assets are accounted for at an amount, that does not exceed their cost of reimbursement (Figure 1).

International Financial Reporting Standards require the calculation of impairment losses on assets. For the purposes of calculating impairment losses, the CGU is accounted for at the highest of two types of cost:

- fair value less costs to sell (market value);

- values of use [9].

As noted, when accounting for $\mathrm{CGU}$ and specialized equipment from the standpoint of their value at the time of restructuring, all assets and liabilities are measured at fair value in accordance with IFRS.

According to National standard 1 «General principles of property and property rights valuation» (hereinafter referred to as NSE 1), the fair value of specialized property can be determined by the following type of value: the market value will be equal to the residual value of the replacement (reproduction) [8].

Provide an explanation of the different economic interpretations of substitution value and cost of reproduction, since in NSE 1 these types of cost are combined, and it is generally felt that this is an identical valuation base, although in practice it is a completely different kinds of value.

Replacement cost - determined at the date of valuation, current cost of creating (acquiring) a new object like that to the valuation object, which may be an equivalent replacement [8]. 
Recovery Cost - determined at the date of valuation current cost of the reassessment of creating (acquiring) in a modern environment a new object identical to the object of assessment [8].

Replacement Cost (Replacement) - is the cost of replacement (reproduction) of the object of valuation minus all types of wear [8].

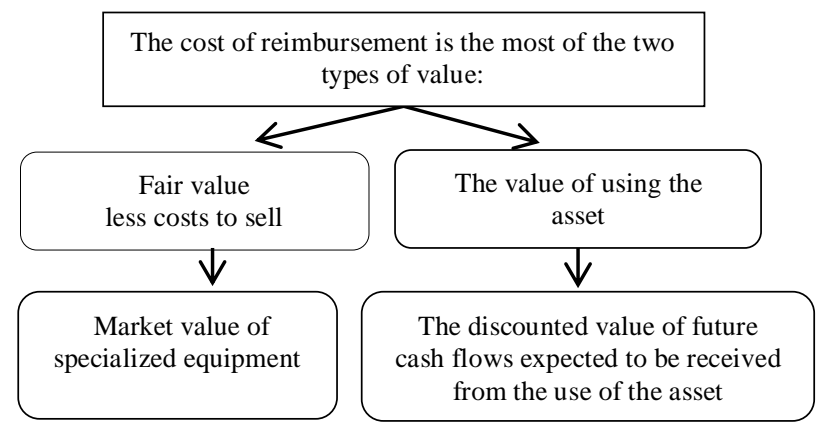

Fig. 1. Determining the cost of compensation in accordance with IFRS 36 «Impairment of Assets»

Source: generated by the author using the information [9]

According to NSE 1 item 22 cost of specialized property is measured at residual value of substitution or reproduction, which is calculated, based on the cost approach only [8].

If the terms of the transaction of specialized property transactions corresponds to the requirements for determination of market value, the residual value of replacement (reproduction) may be equal to market value.

According to IFRS 16, fixed assets, including specialized property, can also be measured at cost in use, which is calculated, based on the current conditions of use of the object of assessment and may not match its most effective use [10].

Summarizing indicated types of valuation of specialized property, based on the rapidly changing trends in the economy of Ukraine, the valuation of the specified property at such value as residual value of replacement or reproduction, does not reflect the real value of specialized property. Since the algorithm of valuation of property is costeffective approach provides for availability of doubt calculations as for the reproduction of property, that is usually no longer commercially available, and the materials from which it is made of, are impossible to be found in order to create almost completely identical analogue. From this, it follows that it is possible and economically impractical to release such specialized property as of the current date, since in the age of high technology there are already exist analogues, that are more powerful in technical terms, and can produce more high quality products. So, see that the problem of correct consideration of physical and moral wear appears to be at the forefront. This problem can be solved by using a cost approach, because at this time, even in the absence of technical documentation and accounting records, there is a scale of physical wear, that can be determined by engaging an expert and based on an external review [11].

In our opinion, moral depreciation should be calculated by the following formula:

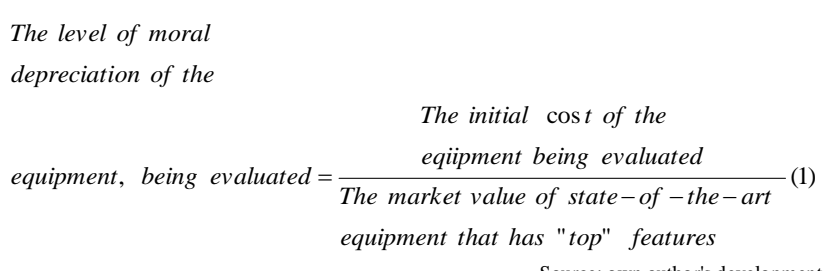

The definition of all types of wear (physical, moral and socio-economic (this type of wear is extremely difficult to calculate, so in practice it is usually not counted in Ukraine)), in our opinion, is correct, when the term of use of the specialized equipment does not exceed 50\% of the possible term of use. Then these types of depreciation will be calculated at the most identical to the real value of the property at the current date. Meanwhile, the use of a cost approach to calculate the residual value of the replacement (renewal) of specialized property, does not take into account the most important aspect of any entity's activity at this time - each asset should bring to its owner an increase in economic benefits or a decrease in liabilities (otherwise it cannot be called as asset), so it is advisable to focus on accounting and analytical tools, that is able to account the revenue component when determining the value of specialized property. Therefore, it is logical to focus on the type of value, that allows to determine the revenue, generated by specialized property.

As for valuation of specialized property at cost in use, the specified type of value is used when the specialized property is intended to be used in the planned or existing way. Therefore, this type of value, while taking into account the proceeds of the use of this asset, according our opinion, does not always reflect the atypical conditions of use of specialized property. Under typical terms of use mean transactions with property, that occur from the time the enterprise undergoes the restructuring process.

\section{THEORY AND HYPOTHESES/RESEARCH QUESTIONS DEVELOPMENT}

Since the assets of the enterprises are valued at fair value during the restructuring, consider that this type of value as marketable, cannot be acceptable for valuation of the specialized property, since one of the criteria for the possibility of using the said type of value is the presence of analogues on the market, and thus, the use of comparative approach. Specialized property, at least in the chemical industry, cannot be purchased on the market, it is produced according an individual order (for example, a production line with ammonia production). Therefore, the management of such property arouses unusual interest, and the kind of value, that allows to take into account all the above mentioned aspects is a special value.

"Special Cost - is the sum of the market value and the premium up to, which is formed by the presence of atypical motivation or special interest of potential buyer (user) in the object of estimation [8]."

According to paragraph 27 of NSE 1, special value cannot be applied in the valuation of the collateral, the determination of the amount of damages and the amount of direct losses [8]. 
It should be noted, that the method of calculating the allowance is not specified in any foreign and domestic normative document, which regulates the process of property valuation. Allowance for atypical conditions for the use of specialized property, must take into account the lost profit, which must be calculated according to the accounting and business plan of the development of the company.

For a clearer presentation of the problem of valuation of specialized property in Ukraine, let us give an example of the court practice of the crane-building enterprise, whose production facilities were located in Odessa. The said company was a bankrupt. Incorrect valuation of the fair value of the specialized equipment of the specified enterprise, resulted in damage to the state budget of Ukraine during the sale of the production facilities of the cranebuilding enterprise. Characteristics of types of value of the specified enterprise-bankrupt are given in Table. 1.

TABLE I. KINDS OF VALUE OF INTEGRAL PROPERTY COMPLEX OF THE CRANE-BUILDING ENTERPRISE, MLN. HR

\begin{tabular}{|c|c|c|c|}
\hline Kind of cost & $\begin{array}{l}\text { As of } \\
\text { the end } \\
\text { of } \\
2015\end{array}$ & $\begin{array}{l}\text { The sale price } \\
\text { of the } \\
\text { building } \\
\text { crane- } \\
\text { building } \\
\text { enterprise } \\
\text { in } 2018\end{array}$ & $\begin{array}{l}\text { As of } \\
\text { May } \\
2019\end{array}$ \\
\hline $\begin{array}{lr}\text { Market value } & \text { calculated at } \\
\text { property-based } & \text { approach } \\
\text { (including VAT) } & \\
\end{array}$ & 10,2 & \multirow{3}{*}{189} & 25,5 \\
\hline $\begin{array}{l}\text { The investment value is } \\
\text { calculated according } \\
\text { to the financial recovery plan } \\
\text { (including VAT) }\end{array}$ & 45,4 & & 113,4 \\
\hline $\begin{array}{l}\text { The investment value calculated } \\
\text { on the income approach } \\
\text { according to the business plan } \\
\text { (including VAT) }\end{array}$ & 42,0 & & 105,1 \\
\hline
\end{tabular}

Based on management data, as of the end of 2015 , the market value (including VAT) of the said enterprise equaled 10.2 million UAH; the investment value calculated according to the financial recovery plan (including VAT), amounted to 45.4 million UAH. According to statistics in 2019 as compared with 2015, the depreciation of the domestic currency - hryvna was $300 \%$. The calculation was taken at a rate of $250 \%$ of depreciation, as it was taken into account the growing moral depreciation during 2015-2019.

The problem of determining the value of specialized property of the specified crane-building enterprise is, that during the sale of the production facilities, in the process of evaluating the value of the integral property complex, which is the building of the plant management, the morally and physically worn property, was evaluated only according the cost approach, since such approach is indicated in NSE 1 [8]. It was important to further evaluate this property with a profitable approach, since even morally obsolete specialized property can also generate income, as it is now similar and analogue can not be produced.

The said enterprise was bankrupt at the time of the sale and its specialized property did not generate income, and its cost according to the income approach is much lower, than that calculated by the cost approach.
Our calculation of the specialized property of enterprise using this type of value as a special value, takes into account changes in the generation of income by assets (formula 2).

$$
\begin{gathered}
\text { Special value of } \\
\text { specialized property }
\end{gathered}=\frac{\text { Cash Flow }}{\mathrm{R}}+\mathrm{N}
$$

where, Cash flow - net cash flow from operating activities; $\mathrm{N}$ - allowance; $\mathrm{R}$ - discount rate. Source: own author's development.

The discount rate is calculated on a cumulative basis by us as the sum of risk-free rate and risk premium.

The risk-free rate - is the rate of return of the safest, according to the investor, investments.

Domestic economists now state, that the vast majority of state-owned assets are undervalued and the available methodological instrumentarium used by appraisers and accountants are imperfect. According our opinion on this occasion: the available methodological instrumentarium is completely identical to international methods of valuation of property and property rights, however, today in Ukraine there is confusion connected with the question of correct determination of the discount rate, at which it is necessary to evaluate the value of assets of domestic enterprises.

It was noted earlier, that in Ukraine the discount rate is determined by the cumulative approach, and a critical analysis of the components of this rate shows, that, as of 2019-2020, the correct determination of the risk-free discount rate is the actual problem, since it reflects the risks that should be taken on himself an investor, who will develop business in Ukraine. According our opinion, the components of a risk premium for investing in a particular enterprise are not as difficult to determine, because the valuer communicates with the enterprise accounting, and has sufficient information to determine the components of the individual risk of a particular enterprise. Here is a description of the main approaches to calculating the risk-free discount rate ( $\mathrm{R}$ risk-free.) (Table 2). A valuer must work with the recognised techniques and, in the case of specialised property, these are methods that go back to analysing value from first principles by identifying the value of the property to the business [13].

TABLE II. METHODICAL APPROACHES TO DETERMINE THE RISK FREE DISCOUNT RATE (R RISK-FREE)

\begin{tabular}{|c|c|c|}
\hline Author & $\begin{array}{l}\text { Relevance } \\
\text { period }\end{array}$ & $\begin{array}{l}\text { Characteristic of the methodological } \\
\text { approach to determining the risk- } \\
\text { free rate }\end{array}$ \\
\hline $\begin{array}{l}\text { S.A. } \\
\text { Puzenko } \\
{[14]}\end{array}$ & $2000-2015$ & $\begin{array}{l}\text { The rate on bank deposits fluctuates } \\
\text { at a level of } 2-5 \% \text { before deduction } \\
\text { of the income tax }\end{array}$ \\
\hline $\begin{array}{l}\text { Practicing } \\
\text { appraisers }\end{array}$ & $\begin{array}{l}\text { Always } \\
\text { relevant }\end{array}$ & $\begin{array}{l}\text { National Bank of Ukraine refinancing } \\
\text { rate }\end{array}$ \\
\hline $\begin{array}{l}\text { The author's } \\
\text { judgment }\end{array}$ & $\begin{array}{l}\text { During an } \\
\text { unstable } \\
\text { economic } \\
\text { state } \\
\text { Ukraine }\end{array}$ & $* \mathrm{R}$ risk-free. \\
\hline $\begin{array}{l}\text { The author's } \\
\text { judgment }\end{array}$ & $\begin{array}{l}\text { Providing } \\
\text { stable } \\
\text { economic } \\
\text { condition } \\
\text { in Ukraine }\end{array}$ & $\begin{array}{l}\text { Bonds on Domestic Government Loan } \\
\text { nominated in the respective currency, } \\
\text { depending on their maturity (in } 2017 \text {, } \\
\text { it was between } 14 \text { and } 14.85 \% \text { in } \\
\text { hryvna, up to } 18-19.5 \% \text { in } 2019 \text { ) [10] }\end{array}$ \\
\hline
\end{tabular}


The data analysis of the table. 2 showed, that existing long-standing approaches for practitioners and theorists as for definition of a risk-free rate of $2-5 \%$ (as printed in foreign publications [14, p. 37]), are irrelevant for the Ukrainian economy from 2015 to 2019 , as hostilities on the territory of our country, reduce its investment opportunities.

If to come down to the nature of the risk-free discount rate, it reflects the guaranteed return on the investment, that the investor will receive without experiencing any risk.

Therefore, the transfer of the essence of the risk-free rate to the state of the economy of Ukraine, leads us to the budget will be spent by the government to ensure minimum stability and economy in the presence of instability of the external environment. Therefore, it is advisable to use the proposed accounting and analytical tools (Formula 3) for correct calculation the risk-free discount rate when estimating the value of specialized property during the volatile economic state of the country.

$$
* \text { R risk }- \text { free }=\frac{P+V+M}{D}
$$

where, $\mathrm{P}$ - Retirement benefits; V - Expenditure on government needs; $\mathrm{M}$ - The cost of medicine; D - state budget revenues.

Source: own author's development

Using data as for revenues and expenditures of the consolidated state budget of Ukraine in 2015 and 2018 (Table 3), calculated the risk-free rate during the specified periods.

TABLE III. REVENUES AND EXPENDITURES OF THE CONSOLIDATED STATE BUDGET OF UKRAINE IN 2015 AND 2018, MLN.HR.

\begin{tabular}{|l|c|c|}
\hline \multirow{2}{*}{\multicolumn{1}{|c|}{ Indices }} & \multicolumn{2}{c|}{ Years } \\
\cline { 2 - 3 } & $\mathbf{2 0 1 5}$ & $\mathbf{2 0 1 8}$ \\
\hline Revenues & 534694,8 & 928108,3 \\
\hline Expenditures, including & 679871 & 1250174 \\
\hline Retirement benefits & 99587 & 157941 \\
\hline Expenditure on government needs & 52016 & 97024 \\
\hline The cost of medicine & 71001 & 115848 \\
\hline
\end{tabular}

Source: [16; 17]

Risk-free rate in the period of unstable economic situation of Ukraine at the end of $2015=(222,604$ million UAH / 534,694.8 million UAH) $\times 100=41.6 \%$.

Risk-free rate in the period of unstable economic situation of Ukraine at the end of $2018=(\mathrm{UAH} 370813$ million / UAH 928108.3 million $) \times 100=40 \%$.

Author's calculations of the market value of the factory management building of the specified crane-building enterprise (Table 4).

$$
\begin{aligned}
& \text { Market value of specialized } \\
& \text { property at the end of } 2018
\end{aligned}=\frac{34,02 \mathrm{mln} \cdot \mathrm{hr}}{0,4}=85,05 \mathrm{mln} . \mathrm{hr} \text {. }
$$

In our calculations of the value of specialized property of the crane-building enterprise, the discount rate was taken at the level of the risk-free rate, calculated according to our methodical approach (see formula 3). At the same time in a more thorough evaluation of the specialized property of any enterprise, it is necessary to take into account the specific risks, inherent to its production and financial activities.

These compound discount rates are components of the risk premium. It can possible to be calculated by a factor of 2 from the size of the risk-free discount rate. The risk premium must take into account the following specific types of risks, inherent to the use of specialized property: the risk of quality management can be up to $20 \%$; availability of technical documentation; the cost of commissioning.

TABLE IV.

CALCULATIONS OF THE MARKET VALUE OF THE PLANT BUILDING OF THE INTEGRAL PROPERTY COMPLEX OF THE CRANE-BUILDING ENTERPRISE, APPEARING IN THE COURT PROCESS, CONCERNING THE DAMAGE TO THE STATE BUDGET OF UKRAINE

\begin{tabular}{|l|c|}
\hline \multicolumn{1}{|c|}{ Kind of cost } & $\begin{array}{c}\text { Sum, } \\
\text { mln. hr. }\end{array}$ \\
\hline Actual sale price of the building (including VAT) & 189,0 \\
\hline $\begin{array}{l}\text { Market value, calculated on the basis of income approach, } \\
\text { calculated by the author, by the method of direct } \\
\text { capitalization (including VAT) }\end{array}$ & 85,05 \\
\hline $\begin{array}{l}\text { The results of the court experts' calculations } \\
\text { (information taken from the materials of the public hearing } \\
\text { of the criminal case) (calculated by income approach) }\end{array}$ & 85,0 \\
\hline
\end{tabular}

Source: own author's calculations and materials of public hearing of a criminal case at a court hearing

Any economic activity of the enterprise is accompanied by risk which is serious threat of its economic security, underestimation of the negative consequences of risk can turn even quite successful firm into the bankrupt with all that it implies. In scientific literature a lot of attention is paid to determination of enterprise risks, their classification [18], but all authors meet in one: the risk is always threat of loss of the capital, the real estate, property and image of economic entity [19]. Assessment of financial risk plays an important role in process of management of risk, creating a basis for a decision making and assessment of their effectiveness [20].

\section{CONCLUSIONS}

Generalization of international and domestic experience in determining the value of specialized property of enterprises, allowed us to develop accounting and analytical tools for estimating the fair value of these assets, taking into account the goals and interests of economic entities, interested in transparent purchase and sale transactions. The main aspects of the proposed toolbox are as follows:

- The fair value of specialized property must be calculated by estimating the special value of the property.

- The comparative approach does not make it possible to calculate the fair value of specialized property, because there is no developed market for similar specialized property.

- The cost approach must be taken in conjunction with the calculation of the value of the specialized property, since it provides more accurate results and complies with the principle of the best use, which obligatory must be taken into account when assessing the value of property and property rights.

- The methodology for calculating the allowance, which is part of the special value of the property, must take into account the lost profit, which must be calculated according to the accounting and business plans of the enterprise. 
- As a risk-free rate in determining the special value of specialized property with stable economic condition of the country, it is necessary to take bonds of the domestic government loan.

- In the unstable economic situation of the country, it is advisable to choose the proposed coefficient: (Retirement benefits + expenditures on public needs + expenditures on medicine) /state budget revenues) as a risk-free rate.

- The risk premium is calculated by a factor of 2 from the size of the risk-free rate, since the term of exposure (sale) of specialized property, is much higher than other types of fixed assets.

\section{REFERENCES}

[1] J. Pinto, CFA, E. Henry, CFA, J. D. Stowe, CFA and T. R. Robinson, CFA Equity Asset Valuation, 2nded, John Wiley \& Sons, New Jersey, USA, 2016

[2] V. E. Esypov, Otsenka biznesa [Valuation], Pyter, Russian Federation: PRTeam, 2014.

[3] D. Jansen van Vuuren, «Valuing specialised property using the DCF profits method», Journal of Property Investment \& Finance, vol. 34, no. 6, pp. 641-654, 2016. doi.org/10.1108/JPIF-06-2016-0047

[4] R. Farthing, The Valuation of Specialised Operational Assets Unbundling Enterprise and Asset Value, no. 2, pp. 35-40, 2010. [Online]. Available: https://search.informit.com.au/documentSummary; dn=355667136990 542;res=IELBUS>ISSN: 0313-5934. Accessed on: Sep. 15, 2019.

[5] I.V. Zhigley, and I. A. Yukhimenko-Nazaruk, "Development of accounting valuation of specific assets", Problems of theory and methodology of accounting, control and analysis, no. 3(38), pp. 61 70, 2017. [Online]. Available: http://pbo.ztu.edu.ua/article/viewFile/ 122258/117574.pdf. Accessed on: August 10, 2019.

[6] M.V. Koryagin, Accounting in the enterprise value management system: theoretical and methodological concepts. Lviv, Ukraine: LCA., 2012. [Online]. Available: http://www.lac.lviv.ua/ fileadmin/www.lac.lviv.ua/data/kafedry/Buh_Obliku/Docs/Bukhgalte rskii_oblik_u_sistemi_upravlinnja.pdf. Accessed on: August 12, 2019.

[7] V. N. Trishin "About valuation of specialized and quasi-specialized property, plant and equipment", Evaluation issues, no. 3, pp. 2-28, 2009. [Online]. Available: https://www.audit-it.ru/articles/appraisal/ a108/303871.html. Accessed on: August 10, 2019.
[8] Cabinet of Ministers of Urkaine 1st Session. (2019, august 3). Decree № 1440, About approval National Standard 1 "General Principles of Property and Property Rights Valuation". [Online]. Available: https://zakon.rada.gov.ua/laws/show/1440-2003 \%D0\%BF. [in Ukrainian].

[9] Ministry of Finance of Ukraine. 2 nd Session. (2019, august 1). IFRS 36 "Impairment of assets". [Online]. Available: https://www. minfin.gov.ua/uploads/redactor/files/IAS\%2036_ukr_2016.pdf. [in Ukrainian].

[10] Ministry of Finance of Ukraine. 2 nd Session. (2019, august 1). IFRS 16 "Capital assets". [Online]. Available: https://www.minfin. gov.ua/uploads/redactor/files/IAS\%2016 ukr 2016.pdf. [in Ukrainian].

[11] S. I. Bolshakov, Appraisal of tangible assets: estimation of the market value of machinery and equipment. Odessa, Ukraine: O. S. Popov Odessa National Academy of Telecommunications, 2009. [in Ukrainian]

[12] Y. O. Repushevskaya, "Formation of anti-crisis management decisions in the activity of machine-building enterprises", Extended Abstract of Cand. Econom. Sci. Diss., Accounting and Economics faculty, Odessa National University of Economics, Odessa, Ukraine, 2016. [in Ukrainian].

[13] N. French, «The valuation of specialised property: A review of valuation methods», Journal of Property Investment and Finance, no. 22, 2004. doi: 10.1108/14635780410569506

[14] S. A. Puzenko, The basis of estimation theory. The order of carrying out of independent estimation in Ukraine. Kyiv, Ukraine: FADA LTD, 2007.

[15] Results of the placement of bonds of domestic government loans. [Online]. Available: https://bank.gov.ua/control/ uk/bonds/list. Accessed on: August 12, 2019.

[16] Budget of Ukraine: expenditures. [Online]. Available: http://cost.ua/budget/expenditure/. Accessed on: August 12, 2019.

[17] Implementation of the state budget of Ukraine. [Online]. Available: https://index.minfin.com.ua/ua/finance/budget/gov/. Accessed on: August 12, 2019.

[18] M. I. Korolev, Economic security of firm: theory, practice, strategy choice. - M.: Economy, pp. 152-170, 2011.

[19] N.V. Manokhina, Economic security: studies. a grant / under the editorship, M.: INFRA-M, pp. 176-186, 2014.

[20] O. V. Martynenko, O. N. Makarova, Yu. N. Makarova, «Role of Financial Statements of the Production Enterprise at Assessment of Risks and Threats of Foreign Economic Activity», in Proceedings of the International Scientific Conference "Far East Con" (ISCFEC 2018), pp. 278-281, 2019. doi.org/10.2991/iscfec-18.2019.70 